IDEA - Studia nad strukturą i rozwojem pojęć filozoficznych $\mathrm{XXIX/2}$ Białystok 2017

\author{
Nelson Udoka Ukwamedua, \\ Moris K. O. Edogiaweri \\ (Abuja, Okada, Nigeria)
}

\title{
THE TYPOLOGY OF SPIRITS IN IGBO-AFRICAN ONTOLOGY: A DISCOURSE IN EXISTENTIAL METAPHYSICS
}

\section{Introduction}

Gleaning from tradition, history, experience and research, it is bare-faced that the African ontology is incomplete without the transcendental and metaphysical domain. As a matter of fact what differentiates the African ontology from others is the seeming inevitable alliance between the physical and the super-physical realm. A typical explanation and illustration of this submission is blatant in Edeh's work Towards an Igbo Metaphysics (1985) where he outlined the three broad categories of beings with sub-categories. The first category is: Spirit and Forces. The subs in descending order are (i) the Supreme Deity (Chukwu/Chineke (ii) Powerful Spirit (Agbara) (ii) Ancestral Spirit (Ndichie) (iv) Spirit of the dead, (v) human Spirit, (vi) Spirit associated with the personality of all things, (vii) forces which may be phenomena, or related to certain human endeavours, (viii) forces which are immanent in natural objects, (ix) Evil spirit- devil (akalaogoli, ogbanje). In the second category: Human being (Madu) in descending order (i) Priests (Ndiezemmuo) (ii) Diviners (DibiaAfa), (iii) Medicine men (NdidibiaOgwu), (iv) Elders (NdiOkenye) (v) Wealthy/titled men (NdiOgaranya/NdiNzenaozo), (vi) Ordinary men (Ndiefu) (vii) Women and children, (viii) the unborn. In the last category are: (i) Animals (including birds and insects), (ii) Plants, (iii) inanimate objects and elements. Interestingly 
and most importantly for this research, each of these beings is permeated by spirits and forces. So, among the Igbo-Africans, the belief in a supreme deity and the hierarchy of spiritual beings is commonplace, and there is invariably a sustained strong belief in the existence of spirits. These spirits dwell in rivers, hills, farm and even lightening. Most of the spirits are particular, but some for example ala (earth spirit) is universal throughout Igbo land. The Igbos address some of these spirits in their prayers as every human enterprise is believed to be governed by the spiritual powers that reward or punish defaulters in the sphere of life. The spirits are above man but below the supreme being, these spirits are in charge of operations. So, spirits of various kinds are key to the existential situation of the Igbo-African. This state of affairs precipitated the interest of this research which seeks a further and farther analysis and understanding of the ontological status of these spirits with special attention on their typology.

\section{Understanding Religion In Igbo Philosophy}

Igbo traditional religion is the indigenous religion that has been handed down from generation to generation by the ancestors. It is a religion the Igbo have made theirs by living and practicing it. Nwala (1985 76) opines that "traditional means what is prior to the impact of Western education". The traditional religion has no written literature, yet it is largely written in people's myth, folktales, songs and dances, liturgies, proverbs and pithy saying. It is a religion whose founder is neither unknown, worshipped and has no zeal for membership drive. Yet is offers persistent fascination for the Igbos young and old, rich and poor alike. Igbo traditional religion reflects a conception of man's relationship with external nature in which forces are apparently bound in order to achieve his sole aim. It dwells much on such concept as God, human life, magic and above all spirit. It equally incorporates some essential activities like practices, ceremonies and festivals. It also comprises an institutionalized system of symbols, beliefs, values and practices focused on ultimate meaning. In this religion, there is high regard for places and object of worship (Ifesieh 1989, 152). The Igbo religion has much to do with moral code of conduct (nsoala) which is embodied in traditional customs (omenala) which is the corpus of most of the legal, social, rural and ritual norms of the people. The religion abhors any transgression against the moral values, which disrupts the ontological order set up by the supre- 
me God. The presence of some people such as priest, medicine men and diviners abound in Igbo religion, this is based on the fact thatthey are the ones to perform the various religious practices like; ceremonies, sacrifices, divination etc.

\section{Believe in the spirits}

The profound and ardent perception the Igbo-Africans show to God stem from their strong belief in the existence of and in their cognition of the place of God as the supreme spirit. But Ala (earth spirit) is the most important spirit after Chukwu who is the supreme spirit (Arinze 1970, 12). Obviously, Igbo are very much aware of the reality of spirits. They mention them in several of their prayers. Equally there is strong belief in the existence of non-human spirit. It is interesting too that the various natural phenomena are personified with the spirits, as for them, the spirits dwell in rivers, streams, hills etc, they also use the days of the week to personified these spirits. They also recognize and appreciate the spirit of destiny, of the household, of fruitfulness and of fertility. And most of those spirits are localized while some are universally in nature hence they are worshipped throughout Igboland. There is also this firm Igbo belief that these spirits have power to interfere positively or negatively onhuman endeavours and aspirations. This firm belief seems to be the underlining basicsof their relationship and interactions with them, and this is vivid in human guilt, prayer and sacrifices. In Igbo-African belief system, these spirits are numerous and are known with many names like; ndimuo, alusi, or agbara etc. The spirit whose names are known have their cult as well as his/her priest and feast day. Interestingly, most of these spirits have sacred animals attached to them. These spirits also have gender differentiation, some are regarded as male while some are female and as such determine the type of case that would address to each. On the whole,the total life of the Igbo-African seems to be entangled with the continuous fear of the spirits and this accounts for whythe spirits are rated high in their whole life and events. According to Nwala $(1985,37)$, "spirits possess couple attributes depending on the order in which it is being spoken of, but generally spirit (muo) is said to process vital influence and force or power, which may be described visible in the process of its action. 


\section{Interaction with the spirits}

The Igbo-African ontology shows a close bond between the visible and the invisible, the divine and human beings. The Igbo-African basically does not subscribe to any form of dualism but they rather they appreciate and understand the human person only as a single unit, but this unit is characterized by a network of relationships. Man is seen in his relationship with God, his alliance with the spirits-word, and his close connection with the entire community of human being and nature (Nwagbala 2003, 84). The spirits are innumerable in Igboland; some are friendly while others are bad and wicked. Mbiti (1977) speaking about Africa in general which vividly capture the Igbo-African scheme even reiterated the fact that the majority of the spirits cannot be classified as either good or bad. This is hinged on the fact that whether they are felt as good or bad depends on how people experience the force of nature (in effect, the nature spirit) and also how these nature-forces act and react towards human beings and their operations.However, it can be undoubtedly stated that the primary disposition of Africans is to live in harmony with humanity and nature. Thisindeed is a salient ontological principle in man and this informs and enable man's disposition towards an ontological relationships with the realities around him. This underscores the fact that man in Igbo-African tradition is best described as being in relation, a relational being. And for Metuh;

The goal of interaction of beings in African world-views is maintenance of the integration and balance of the Beings in it. Harmonious interaction of beings leads to the mutual strengthening of the beings involved, and enhances the growth of life. A harmful influence from one being weakens other beings and threatens the harmony and integration of the whole. Thus, one of the bases on which the African mode of life rests is participation or profound communion with the universe (Metuh 1978, 70-71).

Man strives to be in harmony with God, the deities and his fellowmen both living dead. The relationship that exists between man and spirits can be termed 'symbiotic' it is a mutual and reciprocal genre of relationship. Man feed the gods and the gods provide health, fertility of the soil and reproduction for man. Human beings manipulate and influence these higher forces through prayer and invocation, rituals, festivities, ogwu or mystical forces. The role of 
the priests, diviners, elders, medicine men in the attempt to secure a proper harmony with these spirits are indeed indispensable. The socio-religious symbiotic form of interaction is seen clearly in the daily lives of the people especially, in their constant element of prayer and invocation. Early in the morning, father of the family pours libations soliciting for God's providence, the supreme God who lives in the sky, all to seek the aid and involvement of the spirits in human affairs. Explicating this further, Oguejiofor says, "in Igbo religious beliefs and practices, man is the focus of divine action, and this man is not a simple passive on looker, but an indispensable participant in the saga of the divinities" (Oguejiofor 1996, 58). This relationship with their spirits has therefore been aptly described as a reciprocal or contractual relation in whom each party is expected to fulfill his own part of the contract.

The spirits are fed with both seasonal and occasional sacrifices; shrines are erected for the public divinities with a priest in charge. These divinities have their taboos, which are strictly observed. Thus, Oguejiofor noted “... having done these, the Igbo expect their divinities to protect them, enrich them, or at least take charge of the particular sphere for which each is cultivated" (Oguejiofor 1996, 58). Furthermore, it is not uncommon that the divinities fail in their duties. When this eventually happens, the Igbo feel no qualms in inviting sanctions on them. The sanctions take different measures depending on the gravity of the failure such sanctions include simple verbal reprimand, offering the divinity fewer sacrifices than usual. An Igbo adage would say, Ikanga Onye Ubiam nata so ojioji (the poor man's Ikenga eats only the kola nut). The divinity may be abandoned and its shrine left unattended to after it is obvious that the divinity has proved ineffective. Also, this might led to the total demolition of the symbol of the divinity. Achebe $(1967,47)$, pictured the scene when he noted in the Arrow of God, that "and we have all heard how the people of Aninta when their deity failed them. Did they not carry him to the boundary between them and their neighbours and set fire on him? In all, the Igbo-African interaction with the divinities is straight forward, they respect the gods and also expect the gods to respect them- humans. Though they acknowledge the power of the gods but they also appreciate the fact that should any of the gods fail, they reserve the right to discard them and seek out new gods. 


\section{Nature of spirits}

The Igbo world is punctuated by two beings visible and invisible. They believe that between God and man there are other beings that populated the universe. Spirits have a status between God and man. The nature of those spirits is a question, which the Igbo do not generally probe; rather they are more interested in their functions. These spirits are believed to have super human powers to help or obstruct man in carrying out his daily mission. They are invisible beings. Diviners could say "Onyefulumuo di? -who sees the spirit and lives. The spirits are above man and below the supreme being. The supreme beingis appealed to, when all these intermediate spirits prove themselves incapable to the task. No thoughtful Igbo man will put God on the same realm with any spirit, no matter how powerful the spirit proves to be. Spirits possesses complex attributes depending on the order in which it is being spoken of, but generally spirits (muo) are said to possess vital influence and force or power, that can be described as supernatural because it is not visible in the problem of its action.

\section{Kinds of spirits}

In categorizing the spirits, the differentiation could be made on these spirits as being good (benevolent) and bad (malevolent), while some may be considered to be neutral or good and bad, like in case of human beings.

\section{Good spirits}

Igbo-Africans are concerned about these spirits which come in contact with human beings. From their experience and practice, those spirits whose names are known and have shrines and priests are generally regarded as benevolent or neutral or severe to those who disobey their laws. The Igbo-African reveres the ancestors, as they are the closest spirit they encounter more especially within their immediate family circle. The Ancestors basically inquire about their families and even ward off any impending danger or rebuke those who have failed to follow their special instructions. They even attend to all those who want to distract the operations and wellbeing of their families They are in- 
deed the unseen guest and presidents at every meal of the family, ceremonies, ritual performance, during the offering of sacrifices and tribal meetings where they perform their duties of guardians and policemen of public morality. This is because, for Kwame Gyekye, they are moral paragons.

Another good spirit is Mbataku (the spirit of wealth). According to Okafor (1992, 23), Mbataku is imagined to be a ram headed spirit whom the Igbo attribute their wealth to. In setting out for journey, a sacrifice of piece of kola is made to it, and this same Mbataku is rewarded according when a success is made or there is a breakthrough. Also, when one's trade faces a slump or strayed animal could not be found. Mbataku is requested to provide better economic opportunities. It is thus a friendly spirit and the Igbo are well disposed towards it based on the implication of its existence in their lives.

Furthermore, Ifejioku is very important and powerful spirit respected by the Igbo. The reason is because this spirit is associated with yam; the crop has acquired some social and religious importance in Igbo land. It is indeed the prince, the first and the most priced of all their farm produce. It is also usually and mainly reserved for men to cultivate and its fruit and product is used to qualify the nature of men in the society. The yam spirit receives his special cult before and after the planting season. As a result of this, Ifejiok $u$ is not a harmful spirit.

In the same light, the cult of Anyanwu is widespread in Igbo land. In some areas Anyanwu is even ignorantly confused with or even identified with $\mathrm{Chu}^{-}$ $\mathrm{kwu}$, the supreme being. Some title names for God in different areas include Anyanwu (sun) as AnyanwuChukwuOkike Anyanwu is regarded in a special way as a deity bringing wealth and good fortune to the people. Typically, as the Igbos go to market they say "I am going to market, may Anyanwu grant that my words may sound sweet to those with whom I trade". Anyanwu is more benevolent than malevolent in relationship with the people. And it is appreciated based on this and its import for their responsible, decent and peaceful living and coexistence.

\section{Bad spirits}

In Igbo thought system, there are hosts of unknown spirits who are regarded as malevolent. Primarily, Ekwensu is regarded as a wicked spirit and has no image and receives no sacrifice. There are some localized spirits who do so little good and greater harm, that they are called wicked. Arinze cities example thus 
"Udo is famous in Igbo land, Okpimodu, Ununnachi, Omaliko at Abatete etc. they delight in inflicting suffering almost capriciously and at the least provocation" (Metuh 1999, 92). Among the bad spirits are dead human spirits who are considered not to be in good relation with human beings.

Akalogoli are the first, they are the wandering spirits of those who died without any offspring or wealth and as a result never received final or even decent burial rites. And based on these, they are unable to reach the spirit land. Metuh observes that flowing from their status they wander, they are restless and also very disappointed and pained about the world and how they were treated in death and mot times during their life time so they try to make life unbearable and if possible useless and meaningless for their surviving relations. Onuigbo pictures the state of these Akalogoli in burial ceremony in Ogwugwu town, Igwekala ceremony is the last rite to be given an ideal man to usher him unto the company of the ancestors, failure to perform this rite means that man's spirit will never be settled among the dead, rather, it will be hovering from place to place disturbing the living. So aja Akalogoli is the sacrifice used to ward off these hopeless spirits, because it is sacrifice that is a means of escape from the evil designs and activities of malignant spirits.

The next in this category is Ogbanje, ogbanje is believed to be children born several times of same or another mother, who decided earlier beforehand in their group when they will die. They existed only to inflict pains on the parents on the course of their eventual death. Ogbanje are wandering spirits who specialize in the sadistic mischief of finding their way into the womb to be born to die. Achebe categorized Ogbanje into two: Ogbanje-Elu (earth spirit being) and Ogbanje-mmiri (water spirit being). For Onuigbo $(2001,62)$ these categories of Ogbanje appear in hierarchical order which determines how long one has journeyed into world and also experiences so far gotten from its repetition. Ogbanje belong to groups and it is the famous feared spirit to be gotten by any young mother. Lucas, $(1970,168)$ describes them as "confraternity of spirits who visits the world in the incarnate form for short periods. The length of each is being prearranged. The spirits are born into babies who die in infancy or boyhood". Ogbanje as a bad spirit always have evil intention. The preoccupation of these Ogbanjes is just to continually torment parents with pangs of constant births and deaths of their children and leave them not only childless but also frustrated at the end of their child bearing age. However, to ward off these bad spirits, the 
rites of Ichuaja (exorcism) are performed to extricate the victim from the bondage of these evil spirits and allow them live normal life.

Lastly, Ogbonuke or Obutaufie as they are called in Abakaliki, is another bad spirit. These evils spirits are the spirits of dead people, just like Akalogoli. They are the spirits of those who were sacrificed, those who were lousy, naughty, useless, lazy, unmarried and those without children. As a result these person during their life on earth had no savings, no decent homes, it also included people who were notorious in criminal acts. More so, women who died during child labour, and those for whom the final funeral rites were not performed are also in this category. Some scholars like Arinze would refer to them as okpalammuo (that is, spirit-possessed, first born of the spirit in the bad sense). So they are properly referred to as evil spirits. Among the Igbo-African ogbanuke- (a dead contemporary) is another class of evil spirits. These spirits represent age-grade members who died not just quite young but also frustrated just as a result of the fact that they were unable to achieve their primary aim and purpose in life on earth- their akala-aka. Consequently, they spirits are seen as terrors and this explains why the Igbos are scared of them because they see them as spirits who act terribly and in bad manner, and even when they are perceived to be irrepressible, they are quite vicious and malignant. The reason is not far-fetched from their frustrated experience and state. They can even ambush their victims by the roadsides anytime of the day or even by night. Their aim is to useless the lives of those alive and they do this by preventing them from realizing their quest of and for longlife, their aspiration to have many wives, children and grand funeral ceremonies which assures them of a place of honour in the spirit land which they have missed already. This belief system then makes the assaulted and molested person to offer a sacrifice (Aja), to ward off such bad spirit and to remain at peace with himself and his household.

\section{The Typology of spirit nn Igbo-African ontology}

In Africa, the structure of spirit-world assumes a pyramid form and at the apex is thesupreme being, on one side of the triangle and the nature gods; on the other side are the ancestors. Flowing from this classification, there are three categories of spiritual being, the supreme being, nature gods and then the ancestors. In Igbo worldview, therefore spirits are classified hierarchically in reverse 
order thus, masquerades, the ancestors, deities and on lipside of the ladder is the supreme being.

\section{Masquerades (Mmonwu)}

The belief and the practice of masquerading is a very important tradition among the Igbos. Hence, masqueradesare considered in the ontological order of spiritual beings among the Igbos. The Igbo believe in the immortality of the soul which is partly proved by their belief in reincarnation. This immortality of soul is practically demonstrated by the practice of masquerading. For the Igbos, the masquerade mmonwu is also another ancestral spirit that is person who wears the mask personate, it appears in public in special seasons, during festival and during the celebration of final funeral rites for the dead. Mmonwu is probably from two words muo (spirit) and onwu (death), hence mmondinwuruanwu (spirit of the those who have died). Mmonwu are visible spirits in the community and they are accorded all spiritual respect. They are believed to be the dead that come to life for special celebrations, such as funeral rite, new yam festival, etc.

\section{The Ancestors}

The next in the hierarchy of spirit being is the ancestor spirit. The Igbo have a strong belief in another life after death. When a person dies, his spirit wanders till it is received into the blessed company of his forbearers, and the basic condition for this reception and admission is that the relation of the deceased on earth must celebrate and complete the full funeral rites and ceremonies. These funeral ceremonies are the only bridge that leads the deceased to rest peacefully and it is the password to the status of an ancestor. The ancestors are the departed whose memories still linger within the families. The spirits are taken to be physically dead but they are still alive. Mbiti prefers the term living dead, in reference to ancestors. The ancestors ensure a smooth flow of transcendental between the physical and the metaphysical world. They were human beings who have experienced all existential problems and now as dead have entered the blessedness of ancestral land by the virtue of final funeral rite accorded to them. In this regard, they are in a position to appreciate the suffering of man. "Being so close to Chukwu he is also in a position to get information from Chukwu for 
humanity" (Madu 1996, 39). The roles Igbo believe the ancestors play are based on the philosophy that they are spirit and therefore have enhanced powers over human beings. The ancestral spirits are highly revered as Igbo land. However, there are threats to their continued existence and relevance today.

\section{Deities}

Deities are localized spirits in Igbo world view. The deities have divine attributes and are worshipped as well based on the recognition of their divine nature. Deities are sometimes referred to as, sons of Chukwu, messengers of chukwu or a mode of the manifestation of the supreme being. For the Igbos, the sacrificesthat are offered to these deities are to be ultimately received by the supreme being, as the former being are only mediators (Shelton quoted by Metuh, 40). All the deities are not related to god in the same manner as the other, rather it is expressed both in language and ritual. There are however, some deities that are central to the Igbos as a whole while a good number are particular or restricted to various communities. A typical example of the deitythat is worshipped by the Igbos in general is Anyanwu (sun). Anyanwu has a special and close association with the supreme deity, this can be seen with the type of sacrifices offered to Anyanwu. This deity called Anyanwu seems to be general and special because it is regarded as the deity that brings wealth and good fortune to the people. For someone who is in habit of dissipating his wealth, a sacrifice to Anyanwu is recommended to him by a diviner.

\section{Amadioha (Sky Deity)}

Amadioha, the spirit of thunder has a wide spread influence in Igboland it even has such local names as Igwe, Kamalu, Ofufe. Igwe is regarded as the son of Chineke and in an interesting twist it is sometimes referred to as the husband of ala (earth deity). And that just as a husband fertilizes the wife; so is this Igwe who in the form of rain fertilizes his wife ala. He is not just seen as the son of Chineke but also regarded as the agent of Chineke against undetected criminals. This deity- Igwe expresses his power and anger in the form offierce thunderbolts and lightening. And those struck down by lightening are not mourned be- 
cause Chukwu (God) is believed to have punished them for their iniquities through his just agent and son-Amadioha.

\section{Ala (Earth Deity)}

Just as Chukwu presides over the sky deities, so ala (earth deity) is believed to preside over the deities below. "Central to the entire existence of the Igbo is the (ala) soil, the land, or the earth. This deity and its nature is so central and vital to the Igbos because it is the land that the ancestors are buried and wherein their souls and bodies also finally rest (ike \& Nnoli 2001, 50). Ala (Earth) is sacred to the Igbo and to commit a crime forbidden was an nso ani- that is an abomination. The earth spirit is regarded after Chukwu, it is seen as the owner and custodian of public morality. By convention, originally, land is not even sold in Igboland as they belief that the land belongs to the community and not to individuals. Among the Igbos, a sale of land implies outright disrespect to the earth goddess, ala.So the Igbos really feel ashamed and also guilty to have to sell any land in the community (Uchendu 1965, 96). Generally, the cult of Ala is very common among the Igbos as each hamlet or village has a shrine and a priest of Ala and these are dedicated to its activities. As the custodian of morality, such sin like adultery, stealing, killing andincest are offences against ala.

\section{Supreme Being}

This is Chukwu, who is all powerful and surpasses all, whether organic, inorganic or transcendental. In this creative aspects, Chukwu is described as Chineke (God who creates) Chi okike or Chioke (creator) Osebuluwa (fashioner of the world). He is just merciful (Chidiebere). Wrong deeds are adequately punished by the lesser spirits on behalf of Chukwu (supreme being). This supreme being does not have temples or shrines, no sacrifices are made to him directly. The supreme being is conceived to be the ultimate creator of all other beings, source and end of morality where other spirits, are his immediate administrator. 


\section{Culminating Reflections}

The Igbo world is populated by a vast number of spiritual being, so much so that almost everything is identified with spirit. Some spirits are harmful while others are beneficial. The supreme being is transcendent and generally detached from man who only recognizes his existence and preeminence through other spirits/deities that are directly known and also closer to the human being. This accounts for the worship and sacrifices made to ancestors and deities. The Igbo-African is strongly convinced of the necessity of the sacrifices, which ranges from petition, expiation, pacification and thanksgiving. This conviction duly stems from the belief that the failure to pay attention to the spirits could lead one into serious calamity. As such, they offer sacrifices to appease higher power and be in union with them. However, a critical look on the Igbo typology of spirit which include masquerade, has left much to be desired. Masquerade does not qualify to be spirit in the strict meaning of the term. This is because spirits possess the attribute of invisibility and bodilessness while masquerade as masquerades seems to be visible and bodied. This is a contradiction in terms.However, it is instructive to state that this mode of ambivalence is a very enduring feature of all religions. This character of the phenomenon of religion is often overlooked in many most recent attempts to come to an understanding of African religion whose real adherents may no longer speak with clear voice. In Igbo religion in particular, it is seems that this chukwu must be both supreme in power and in the reception of worship,otherwise, he becomes a stranger (Nwoga, 1964).

Again, this same supreme being must either be chukwu that it is known for or chi (Ezekwugo, 1987), and must be strictly distinguishable from the personal god chi as though the fluidity of the logic of religious beliefs does not permit his being the supreme being and being in some sense and at the same time personal destiny spirits. Furthermore, chineke is taken to be a double-headed divinity brought into the Holy of Holies of the Christians through the error of the missionaries (Achebe, 1977cf 110 - 112), as though such a double-headed divinity cannot be a manifestation of the supreme being as chineke. In real terms then, it seems vain to fully and really introduce strict logic into the explanation of major religious explanations, symbols or even teachings. This is why in Christianity God who is one has three persons. That is also why Christ is truly God and truly man, divine and incarnate without loosing the feature of any of the two in- 
compatible models of existence. The ancient Egyptians even describes the multiplicity of the divinities as Eneads (nine gods) and Ogdauds (eight gods), but all these together are in a mysterious way one, whether expressed as Atum, Ptah or Amun.

The one and the many becomes the most enlightening presentation of the nature of God among the ancient Egyptians. In the Papyrus of Leiden Atum is the "secret of development but glittering of forms". He is the "manifest one whose identity is hidden in as much as it is inaccessible" (Allen, $1988 \mathrm{cf} 52-53$ ). This incomprehensibility overflows into the mode of operation of all religions. For Oguejiofor (2002), this applies to Christian doctrine about the real presence, to the Hindu symbolism of the cow as well as to Muslims convictions about conversion and proselytizing. In all, some of these religious beliefs, irreconcilable with or simply defying strict logic are understandable only within the realm of the deepest possible symbolism. Undoubtedly, the ontology of the IgboAfrican theodicy seems mono-polytheistic. This underlines the high sense of morality in the traditional Igbo society. And the contemporary Igbos has got a lot to borrow from this system of belief, as its neglect has resulted to the very high level of moral decadence in the contemporary Igbo world. For instance, the attitude towards the sale of land without proper regardand due diligence has become a major mark of the consumeric quest and bolsters the spirit of materialism.

\begin{abstract}
Igbo-African metaphysics remains the most attractive and prominent aspect of IgboAfrican philosophy especially as it is concerned with the ontological scheme of the individual person. This is based on the fact that the Igbo-African life is richly permeated by various kinds of forces and this has remained the primary code to understanding the Igbo-African personality, religion and reality. It is as a result of this premise that this paper sought to appreciate this allimportant aspect of the Igbo-African world and life in lieu of understanding and situating the Igbo-African properly in his/her world. This paper then employed the critical analytic approach coupled with some hermeneutic touch in it task of understanding the Igbo-African and his world. From this analysis, it became quite palpable that the Igbo-African world and its modus operandi et vivendi is closely bond with their interactions with forces and these forces come in various forms and style. This then made it imperative that if any Igbo-African is to live sanely and responsibly, the person must first of all understand and appreciate the origin, existence, nature and mode of operations of the various forces especially spirits-forces because they guide their existence and understanding of reality. It was also blatant that the Igbo-African has to abide by the codes that
\end{abstract}


guide them as it concerns their interactions with the world and the forces around them taking cognizance of the obvious typology.

Key words: Igbo-African, spirits, chukwu, relationship, ancestors, divinities

\section{Bibliography}

Achebe, C. 1967. Arrow of God. London: Heinemann Press.

Achebe, C. 1977. Morning Yet on Creation Day. London: Heinneman.

Achebe, C. 1986. The World of Ogbanje. Enugu: Fourth Dimension Pub.

Allen J.P. 1988. "Genesis in Egypt: The Philosophy of Ancient Egyptian Creation Accounts". Yale

Egyptological Studies. New Haven. Pp . 52-53. As cited by

Arinze, F.A. 1970. Sacrifice in Ibo Region. Ibadan: University Press.

Ezekwugo, C. 1987.Chi the Supreme Being in Igbo Religion.Kerala: Pastoral Institute.

Ifesieh, E.I. 1989. Religion at the Grassroot, Enugu: Foruth Dimension Pub. Co. Ltd.

Ike , N. Nnoli, Understanding Africa. Enugu: CIDJAp, 2001

Leonard, A. 1968. The Lower Niger and its Tribes (ed.) London: Sc. In Press.

Lucas, J.O. 1970. Religion on West Africa and Ancient Egypt, Lagos: National Press.

Madu, J.E. 1996. Fundamental of Religion Studies.Tony Printers.

Mbiti, J.S. (1977). Introduction to African Religion. London: Heinemann Educational Books Ltd.

Metuh, E.I. 1978. Comparative Studies African Traditional religion, Ibandan: Claverianum Press.

Metuh, E.I. 1999. God and man in Africa Religion, Enugu, Snap press.

Nwagbala, E. 2003."Christian Forgiveness (Mt. 6:12) and Igbo Traditional Concept of sin and forgiveness”.Bigard Theological Studies.Vol. 23, No. 1, Jan-June.

Nwala T. U. 1985. Igbo Philosophy, Lagos: Lantern Books.

Nwoga, D. I. 1964.The Supreme God as stranger in Igbo Religious thought. Ekwerazu, Hawk Press.

Ofejiofor, J.O. 1996. The influence of Igbo Traditional Religion on the Socio-political Character of the Igbo. Nsukka: Fulleda Pub. Co.

Oguejiofor, J.O. 2002."The Universal and the Particular in Igbo Conception of Ala" in WAJOPS Vol.5. pp. 22-37.

Okafor, F.U. 1992. Igbo Philosophy of Law. Enugu: Fourth Dimension Pub. Co.

Onuigbo, N.S. 2001. The Histroy of NtuegbeNese (A five town clan). Nsukka: Afro-Orbis Pub. Co. Ltd.

Parrinder, G. 1969. West African Religion. London: The Ep Worth press

Talbot, A. 1952.The Tribes of the Niger Delta.London Fran Crass and Co. Ltd.

Uchendu, V.C. 1965. Igbos of south East Nigeria. New York: Holt Reinhart and Winston.

Dr. Nelson Udoka Ukwamedua - Department Of Philosophy, Veritas University Abuja, Nigeria

Morris K. O. Edogiaweri - General Studies Department, Igbinedion University

Okada, Edo State Nigeria 